\title{
Eustratius of Nicaea, a Theologian: About the Recent Publications of Alexei Barmin
}

\author{
Basil Lourié \\ Leading Research Fellow, Institute of Philosophy and Law of the Siberian \\ Branch of the Russian Academy of Sciences, Novosibirsk, Russia \\ hieromonk@gmail.com
}

Евстратий Никейский, Опровержительные слова. Издание подготовил A.B. Бармин. (Библиотека сборника «Богословские труды»). Moscow: The Editorial House of the Patriarchate of Moscow, 2016. LXIV + 243 pages. Eustratius of Nicaea, $\Lambda$ ó $0 \iota \dot{\alpha} \nu \tau \iota \dot{p} \hat{p} \eta \tau \iota x \circ i$. Edition [with a Russian translation] by A.V. Barmin. (The Library of the Collection "Theological Studies.")

\begin{abstract}
Being the most prominent philosopher and theologian of his epoch (late 11th-early 12th cent.), Eustratius of Nicaea provoked important theological discussions in the fields of both Christology and Triadology. He was eventually condemned (1117) for his Christological views, but his Triadology faced a strong opposition as well. His Byzantine opponents unfavourable to the Latins rejected his logically consistent approach to the Trinity and developed their own non-consistent (paraconsistent) approach, whereas his 13th-century latinophrone opponent Nicetas "of Maroneia" demonstrated that Eustratius's logically consistent Triadology is more naturally compatible with the Filioque.
\end{abstract}

\section{Keywords}

Eustratius of Nicaea - Nicetas Seides - Nicholas Mouzalon - Nicetas "of Maroneia" Filioque - paraconsistent logic 
Eustratius, metropolitan of Nicaea (lived from the middle of the eleventh century to shortly after 1117) is and always has been one of the best-known Byzantine philosophers, especially due to his commentaries on Aristotle. He is also known as a theologian, and very controversial one, but the contents of his works remain understudied, and an important part of them was unpublished until recent time. At the beginning of $2017,{ }^{2}$ eventually appeared the editio princeps of three Eustratius's theological treatises by Barmin, the last items on the list of the inedita. All these works are related to the first major meeting between Greek and Latin theologians, after 1054, which took place in 1112 (or - more probably, according to Barmin - in 1113) in Constantinople.

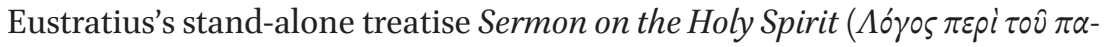

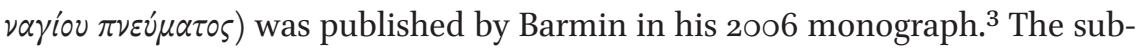
ject of Barmin's recent book is a series of three discourses on the procession of the Holy Spirit written by Eustratius in response to the public speech by Pietro Grossolano. The critical edition is based on five manuscripts (including two of the thirteenth century), provided with a Russian translation (rather good but not to be discussed here) and supplemented with the relevant fragments of Grossolano's treatise where available (in Russian translation only). A detailed historical commentary on works published so far was already given in his 2006 monograph $^{4}$ and is therefore only briefly summarised here. Barmin is commenting, however, on Eustratius's doctrinal views, as they were expressed in the works under publication and elsewhere.

Another study of Eustratius of Nicaea's biography and theological works has been undertaken almost simultaneously by Evropi Papadopoulou-

1 The present study is a part of a larger project $\mathrm{Nr}$ 16-18-10202, History of the Logical and Philosophical Ideas in Byzantine Philosophy and Theology, implemented with a financial support of the Russian Science Foundation. I am grateful to Dirk Krausmüller for improving my English.

2 After having spent near ten years with the publisher and marked as published in 2016.

3 А.В. Бармин, Полемика и схизма. История греко-латинских споров IX-ХII веков [A.V. Barmin, Polemics and the Schisim: The History of the Greek-Latin Quarrels from the Ninth to the Twelfth Century]. (Bibliotheca Ignatiana), Moscow, 2006, pp. 518-565. My review: B.М. Лурье, “На греко-латинском фронте. Размышления по поводу книги: Бармин А.В. Полемика и схизма... [B. Lourié, On the Greek-Latin Front:Thoughts about the book: Barmin

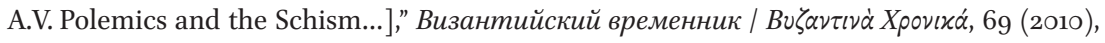
pp. 349-361. Then, I avoided any discussion concerning theological topics in Eustratius, knowing that the publication of Eustratius's remaining works by Barmin was pending. Therefore, my present review article is covering this part of the Barmin's 2006 monograph as well.

4 Within the long ch. 9 "The Constantinople Discussions of 1112-1113" (Бармин, Полемика $и$ схизма, рр. 3о9-358). 
Chatzilazarou. ${ }^{5}$ The two researchers were unaware of each other. Papadopoulou-Chatzilazarou did not take into account Eustratius's works now published by Barmin, and this fact especially affected her understanding of Eustratius's Triadology. In general, her theological analysis, unlike Barmin's one, ignores the immediate (eleventh- and twelfth-century) context of the theological discussions in which Eustratius was involved. Nevertheless, even though her studies are, in theological matters, less informative than Barmin's ones (and skip Eustratius's philosophy altogether), they seem to be useful to a general reader who would like to have a general portrait of Eustratius against the background of his epoch.

After Barmin's studies, the corpus of Eustratius's theological works has become much more accessible and understandable.

Eustratius's theologically most important works are the following. Beside those published by Barmin himself, there are three other pieces of Eustratius's polemics against the Filioque published by archimandrite Andronicus Demetracopoulos in 1866, who included in his first (and the only published)

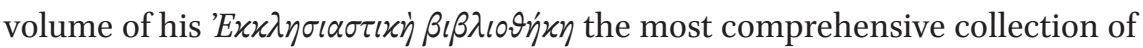
Eustratius's theological legacy. ${ }^{6}$ This collection includes, moreover, one treatise by Eustratius against the use of unleavened bread in the Eucharist and his theological treatises directed against Leo, the metropolitan of Chalcedon, concerning the veneration of the holy icons (the subject of this polemics was mostly Christological) and against the Armenians (Christological as well). Later pieces of Eustratius's anti-Armenian polemics were condemned and burned in 1117, and are therefore known to us exclusively from quotations and summaries made by Eustratius's Byzantine opponents.

Barmin has provided an important addition to the established list of Eustratius's works, having reattributed to Eustratius an anti-Latin treatise $O n$ the

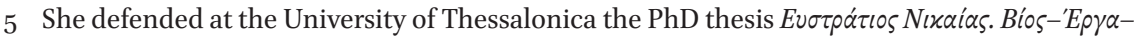

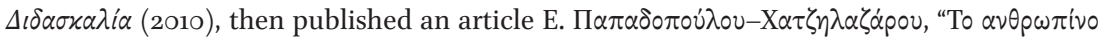

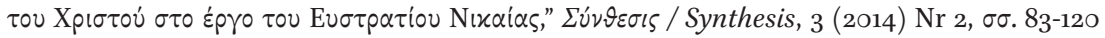
(electronic journal of the Theological Department of the University of Thessalonica <https:// ejournals.lib.auth.gr/synthesis/article/view/4635/4870>), and, finally, published the mono-

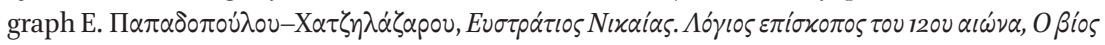

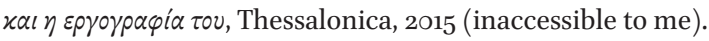

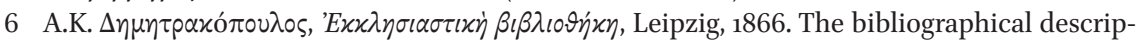
tion by Barmin (p. 228) contains a typo or mistake in the year of publication: 1886 instead of 1866. Barmin provides a review of all literary works by Eustratius. 
Azymes published by the Jerusalem Patriarch Dositheos in 1698 under the name of John, the patriarch of Jerusalem. ${ }^{7}$ It was restored to Eustratius by Barmin according to the manuscript tradition and some peculiarities in contents. ${ }^{8}$

However, another work known in the Greek manuscript tradition under the name of John of Jerusalem, the anti-Latin Synodikon (unpublished; a critical edition is in preparation by Barmin), Barmin considers to be a genuine work of John, ${ }^{9}$ whereas its Georgian version by Arsen Iqalt'oeli is known from

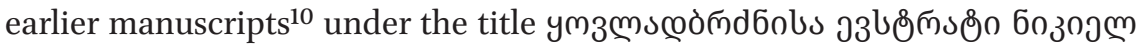

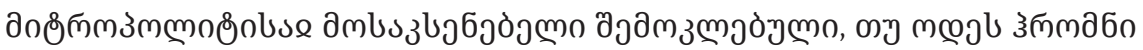

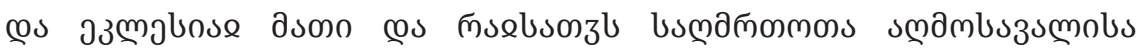

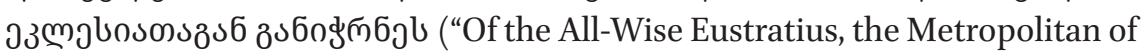
Nicaea, A Short Account on When and Why the Romans and Their Church Separated Themselves from God's Church of the East"). Maia Raphava, who provided the critical edition of the Georgian version, attributes this work to Eustratius. ${ }^{11}$

\section{3}

\section{Eustratius of Nicaea and Niketas "of Maroneia"}

The publication of Eustratius's theological works (now completed, apart from the Synodikon) sheds light on the principal lines of theological thought in

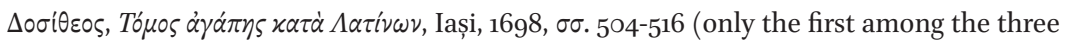
treatises on the azymes published here under the name of John; cf. ibid., $\sigma \sigma .5^{16-538}$, for the two others). It is ascribed to Eustratius in the Greek manuscripts preserved in Moscow; moreover, it contains peculiar anthropological views distinct from those of John in other treatises on the azymes.

8 Бармин, Полемика и схизма, pp. 322-323.

9 Бармин, Полемика и схизма, pp. 287-29о.

10 The Greek manuscripts are of the 13th and 14th centuries, whereas the earliest Georgian manuscript $\mathrm{S}_{1463}$ is dated paleographically to the period from the last quarter of the 11th century to the first quarter of the 12 th century.

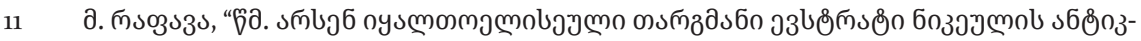

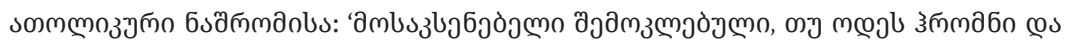

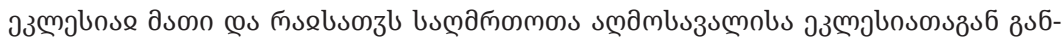

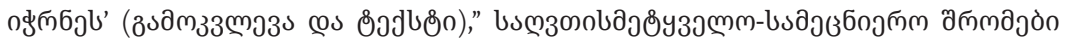
[M. Raphava, "St. Arsen Iqalt'oeli's Translation of Eustratius of Nicaea's Anti-Catholic Work 'A Short Account on When and Why the Romans and Their Church Separated themselves from the God's Church of the East' (the Study and the Text)," TheologicalScientific Works], 5 (2014), pp. 98-162. I am grateful to Alexey Ostrovsky who provided me with further argumentation (still unpublished) based on the Georgian manuscript tradition supporting the authorship of Eustratius. Barmin did not mention Raphava's publication and study in his 2016 monograph; he said me in a personal communication that he remains unconvinced. Obviously, the discussion will be continued. 
Byzantium in the period between the schism of 1054 and the Union of Lyon (1274-1283). A priori this matter was not self-evident. Such a feeling about the importance of Eustratius arose after Barmin's first publication on the topic in 200o, when he demonstrated that some part of the pro-Filioque argumentation of the Greek metropolitan of Thessalonica (roughly around 1165-1170) Niketas "of Maroneia" (a nephew of the bishop of Maroneia) goes back to Eustratius - and not to Latin sources, as it was previously supposed, - and in such an extent that Niketas had repeated him sometimes verbatim. ${ }^{12}$

Niketas became a key figure in the theological preparation of the future Union of Lyon and, then, one of the main sources of John Bekkos's theology. Indeed, Niketas turned Eustratius's arguments against the Filioque in the opposite sense, thus obtaining from them arguments for the Filioque, but he did so mutatis mutandis, without touching the core of Eustratius's understanding of what kind of unity and what kind of difference are present in the Holy Trinity.

Both Eustratius and Niketas were convinced that the Holy Spirit proceeds from the nature of the Father through the Father's hypostatic idiom ( $\dot{\varepsilon} \varkappa \tau \hat{\eta} \varsigma$

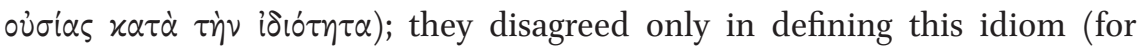
Eustratius, it does not imply an involvement of the Son in procession of the Spirit, whereas, for Niketas, it does). ${ }^{13}$

These theories have in common that, in triadological reasoning, the notion of hypostasis could be substituted with its conceptual constituents, "nature" and "hypostatic idiom." In both theories, the hypostasis is not a kind of whole that is "greater," in some way, than its parts and, therefore, not reducible to the elements which conjunction it seems to be - at least, in divinis, where there is no complexity and no parts at all. We will return to Eustratius's role in these discussions later.

Niketas "of Maroneia" is present in Barmin's 2016/2017 book as well. As an addition to Eustratius's treatises, he published for the first time the ending of Niketas's first treatise on the Filioque (pp. 211-225), which is missing in the edition by Joseph Hengenröther in $P G 139$ (1865) (cols. 169-201).14

12 A. Barmine, “Une source méconnue des Dialogues de Nicétas de Maronée," RÉB, 58 (2000), pp. 231-243.

See, for the parallel texts of Eustratius, Barmine, "Une source méconnue," pp. 235-237; quoted is Dialogue III of Niketas, ed. Festa (s. next footnote), Bessarione, 17 (1913), p. 300. Let us notice that Barmin attributes the publication of Niketas's Dialogues II, III, and IV to Aurelio Palmieri instead of Nicola Festa: p. LXII; Barmine, "Une source méconnue," p. 231 (Palmieri as the editor); cf. Бармин, Полемика и схизма, pp. 424-426 (no mention of the editor at all). The exact reference to this publication should be N. Festa, "Niceta di Maronea e i suoi dialoghi sulla processione delle Spirito Santo," Bessarione, 16 (1912), pp. 8o-107, 126-132, 266-286; 17 (1913), pp. 104-113, 295-315; 18 (1914), pp. 55-75, 243-259; 19 
Barmin's real commentary has few shortcomings. ${ }^{15}$ Normally, it is precise and sufficiently detailed. Eustratius's background in non-polemical theological literature is grasped to a lesser extent, ${ }^{16}$ but this is a consequence of Barmin's general approach - that is rather philological and historical than theological.

In the historical part of his Introduction (which contains an original historical study of the Eustratius affair of 1117), Barmin put forward a somewhat unexpected solution to an old conundrum, the outcome of the ecclesiastical

(1915), pp. 239-246. Aurelio Palmieri published an introductory paper on Niketas in the same journal in 1912, referred to by Barmin, which seems to have provoked this mistake.

E.g., commenting on the term $\beta \hat{\eta} \mu \alpha$ applied to the emperor's throne as the place from where the emperor has to declare his judgment, Barmin refers to the bema of Syrian and Byzantine churches (p. 47, fn. 19), whereas the actual meaning is non-liturgical and very common, already in the Septuagint: "judgment seat." The mention of the $\pi \dot{p} p \gamma \circ \mathrm{X}_{\alpha} \lambda \dot{\alpha} \sim \eta \bar{\varsigma}$ "tower of Chalanes" (p. 72.13) should be commented not with the reference to Is 10:9 alone (in fact, only in the Septuagint version) but, first of all, with an explication that this is another - and quite popular in Byzantium - name of the Tower of Babel; Barmin's explanation of this place (p. 73, fn. 33) misses the point.

16 For instance, in the paragraph of the First Antirrhetics where Barmin proposes remote parallels from Estratius's commentaries in Aristotle and a vague reference to his "Platonism" (p. 22.201-208), one should have recognised a paraphrase of Dionysius the Areopagite, De eccl. hier., v, 7 (PG 3, 508 D-509 A = ed. Heil and Ritter, pp. 109.1-110.5: $\dot{\eta} \theta \varepsilon \alpha p \chi i \alpha$

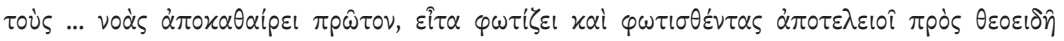

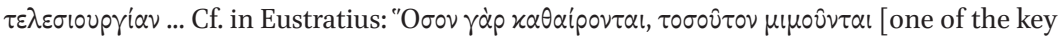

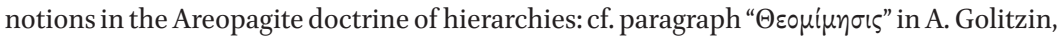
Et introibo ad altare Dei: The Mystagogy of Dionysius Areopagita, with Special Reference to Its Predecessors in the Eastern Christian Tradition. ('Avá $\lambda \varepsilon \kappa \tau \alpha \mathrm{B} \lambda \alpha \tau \alpha \dot{\delta} \delta \omega \nu$, 59), Thessalonica,

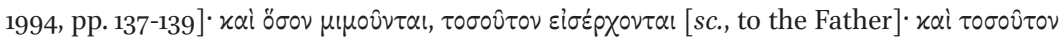

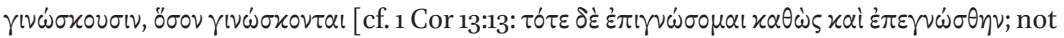

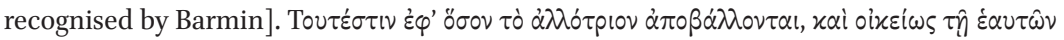

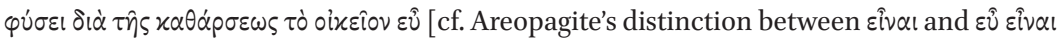
as introduced in De coel. hier., XIII, 4; $304 \mathrm{CD}=$ ed. Heil and Ritter, p. 47, esp. line 9] हे

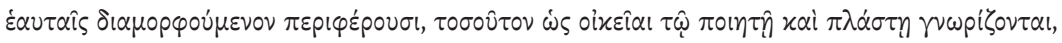
xai $\alpha \nu \alpha \lambda$ ó $\gamma \omega \varsigma$ [another one of the key notions in the Areopagite; cf. V. Lossky, "La notion des 'analogies' chez Denys le pseudo-Aréopagite." Archives d'histoire doctrinale et littéraire

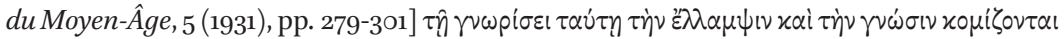

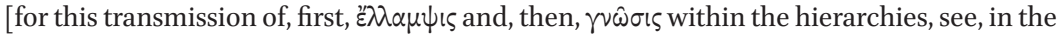
Areopagite, De coel. hier., vII, 3; 209 C = ed. Heil and Ritter, p. 30.15-17; ibid., XIII, 3; 304 A = ed. Heil and Ritter, p. 46.14-16; De eccl. hier., vi, 6; 537 B = ed. Heil and Ritter, p. 119.2326]. In this part of his first Antirrhetics Eustratius elaborates on the Areopagite and not on anyone else. Cf. below on John Italos's influence on Eustratius's Triadology. [In the references above, "ed. Heil and Ritter" = Corpus Dionysiacum II: Pseudo-Dionysius Areopagita, De coelesti hierarchia, De ecclesiastica hierarchia, De mystica theologia, Epistulae, ed. G. Heil, A.M. Ritter. (PTS, 36), Berlin/New York, 1991.] 
trial for Eustratius after his act of penitence. The only document pretending to report the definitive decision, the Thesaurus by Niketas Choniates (1155/11571217), is very late even though it goes back to earlier data. It claims that Eustratius was eventually defrocked. ${ }^{17}$ This is not necessarily true, given that, from the 1117 trial itself, the document containing the definitive decision is lost, ${ }^{18}$ whereas several documents witnessing a hot discussion on Eustratius's fate are preserved. Barmin opts for the hypothesis that Eustratius eventually was banned from liturgical service (without specifying, whether temporarily or forever) but was not defrocked. In Barmin's variant, this hypothesis includes a supposition that the main 1117 documents have the following chronological order (different from their order in the unique manuscript of the preserved dossier, Paris. Suppl. gr. 1179): Niketas of Serres's discourse insisting on defrocking, ${ }^{19}$ the discourse of Patriarch John IX Agapetos proposing the mildest punishment among those theoretically possible (temporary banning from the liturgical service - before the decision of a further synod that will evaluate the fruits of penitence brought by Eustratius), and the voting protocol where the votes of 22 bishops (without the patriarch) diverged ${ }^{20}$ (pp. XXI-XXII).

I would refrain from evaluating any hypothesis in this field, because we still do not understand the real spectrum of the decisions for such affairs, which would have been considered in 1117. Some bishops proposed, for Eustratius, the life-long ban from the liturgical service (instead of the temporary and conditional ban proposed by the patriarch and several other bishops ${ }^{21}$ ), whereas

$17 \quad P G$ 140, $137 \mathrm{~A}$; the only published fragment from book XxiII of Choniates's Thesaurus Orthodoxae Fidei is dedicated to Eustratius ( $P G$ 140, 136 D-137 A).

18 As Jean Darrouzès noticed, "Je crois d'ailleurs que le procès-verbal du vote contenu dans le dossier du Parisinus [Suppl. gr. 1179] ne peut pas être celui du vote définitif contre Eustrate" [J. Darrouzès, Documents inédits d'ecclésiologie byzantine. (Archives de l'Orient chrétien, 10), Paris, 1966, p. 59]. I would add that the voting procedure itself is still not the final one, and the results of the trial must have been formulated in a separate document, the sentence. Barmin considers this voting protocol to be definitive, whereas he says nothing about the necessity of a sentence as the definitive document for the fate of Eustratius (s. below).

19 Darrouzès, Documents inédits, pp. 276-305 (text), cf. pp. 57-62 (introduction). Niketas argued in the line of Methodius of Constantinople and Theodore Studite, and, indeed, from such a point of view, Eustratius, in the case of his penitence, must have been defrocked, whereas kept in communion with the Church as a simple monk. However, Methodius's approach still was, in 1117, far from becoming obligatory for the patriarchate.

20 P. Joannou, "Eustrate de Nicée. Trois pièces inédites de son procès (1117)," RÉB, 10 (1952), pp. 24-34, at pp. 27-29 (patriarch's discourse) and pp. 29-31 (voting protocol). Niketas of Serres's discourse follows, in this manuscript, these two documents. 
preserving his episcopal rank and even his episcopal see, that is, the administrative functions. Indeed, the situation of the bishops who have lost their sees was then not clarified in Byzantine ecclesiastical law, ${ }^{22}$ but the possibility of remaining a ruling bishop without any right for liturgical service seems to run counter to what we know about Byzantine ecclesiology. We can only conclude that our present data and knowledge are not representative enough.

Barmin's conclusion (against previous scholars, especially Périclès-Pierre Joannou) that Eustratius's condemnation was caused by purely theological rather than political reasons (pp. XXIII-XXV) seems to me well founded. Nevertheless, as it seems to me, sometimes Barmin does not realise clearly enough the gap between Eustratius's theology and the mainstream of the Byzantine Orthodoxy as it was represented by the contemporary theologians.

For instance, concerning Eustratius's claim that the Father is to be con-

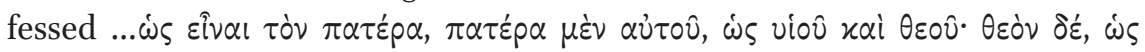
$\dot{\alpha} \nu \theta \rho \omega \dot{\pi} \pi 0 v$ (First Antirrhetics, p. 16.123-125), that is, "...the Father of him [sc., the Son] as of the Son and God, but God as of the human," Barmin comments that "[i]n underlining the difference between the two natures in Christ, Eustratius eventually was confronted with the rejection of his views in the Byzantine Church...," thus referring to the future 1117 condemnation (pp.16-17, fn. 5). However, this phrase does not merely "underline" the difference between the two natures but completely ruins the Byzantine understanding of hypostatic unity: the humanity of Christ is no longer sharing the relation to the Father that is proper to the hypostasis of the Logos.

No wonder that Barmin is sceptical toward Niketas Choniates's evaluation of Eustratius's anti-Latin polemics as having performed oủx $\alpha \dot{\sigma} \varphi \alpha \lambda \hat{\omega} \varsigma$, oủ $\delta \dot{\varepsilon}$ $\varepsilon \pi \alpha i v \varepsilon \tau \omega$ s "not without errors, nor praiseworthy" ( $P G$ 140, 136 D). Barmin (p. Xxx) supposes that these words were provoked by the peculiar arguments

22 To 1117 , Byzantine views on the status of bishops who had been removed from their sees were not established - as it has been shown in 1151 by the discussion about the patriarchate of Nicholas Mouzalon. It resulted in the first apology in the view that it was possible to preserve the rank if a bishop without having a see written by Nicholas of Methone (against Theodore Balsamon who insisted that the bishop resigned from his see is no

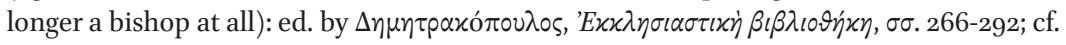
Darrouzès, Documents inédits, pp. 66-74, 310-331. Nevertheless, even Nicholas of Methone did not permit the preservation of the administrative functions of a bishop without the liturgical ones. 
preserved in Eustratius's treatise Sermon on the Holy Spirit and not repeated in the present Antirrhetics. In fact, as Barmin himself notices in his footnotes to the text, these "peculiar" (that is, "mathematical"; see below) arguments were nevertheless repeated in the present Antirrhetics, although in a very brief summary (p. 115, fn. 64; cf. p. XLIII, fn. 117). These arguments did certainly contribute to shaping the Choniates's opinion, but the "Nestorianism" (in the Byzantine sense of word) of Eustratius's argumentation against the Filioque was even more striking.

Normally, Barmin avoids any kind of theological approach, but, fortunately, this does not affect his edition of Eustratius's triadological treatises. ${ }^{23}$

23 Barmin summarises Eustratius's polemics against Leo of Chalcedon (in 1086), which was focused on the veneration of the holy icons but is crucial for understanding of Eustratius's Christology in this early period. He refers (p. XIII, fn. 14) to my two studies on this subject [B. Lourié, "Une dispute sans justes: Léon de Chalcédoine, Eustrate de Nicée et la troisième querelle sur les images sacrées," $S P, 42$ (2006), pp. 321-339 (a detailed account of the theological discussion); В.М. Лурье, История византийской философии. Формативный период <B. Lourié, The History of Byzantine Philosophy: The Formative Period>, St. Petersburg, 2006, pp. 497-514 (a summarised account put into a broader historical content)] and points out what seems to him to be a self-contradiction: I interpret

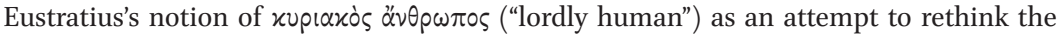
common human nature assumed by the Logos in the Philoponian sense (Лурье, История, pp. 511-512), whereas earlier (ibid., p. 218) I have stated that Philoponos denied the real existence of the common natures. In fact, I have meant that Eustratius called "common" the nature that Philoponos called "particular," whereas, together with Philoponos, Eustratius did not allow the real existence of the common natures in the ordinary = Philoponian sense of word (and this became one of the points of charges against him, when Niketas of Serres accused him of denying the unity of the humanity in Christ and in us). Eustratius returned to Philoponos's mode of thinking (perfectly known to him as Philoponos was one of his most illustrious colleagues in commenting Aristotle), already rejected by the Fathers of Byzantine Orthodoxy in the sixth and seventh centuries (especially Maximus the Confessor). Namely, these Fathers rejected the Philoponian concept of "particular nature" in the sense of a real particular existence without its particularising features (hypostatic idioms); according to them, "particular natures" in any real sense must be the same as the hypostases. Eustratius does not accept this decision because, otherwise, his Christology would become openly Nestorian (the humanity of Christ - which Eustratius separated from the hypostasis of the Logos - would become a separate human hypostasis). Therefore, Eustratius continued to call his de facto Philoponian particular nature of the "lordly human" the common one. Then, he ascribed to this "lordly human" everything applicable to the hypostasis - and all this quite expectedly leaded him to the condemnation as a crypto-Nestorian. For the philosophical and logical context, see now Dirk Krausmüller, 'Enhypostaton: Being 'in Another' or Being 'with Another'? - How Chalcedonian Theologians of the Sixth Century Defined the Ontological Status of Christ's Human Nature," VC, 71 (2017), pp. 433-448; idem, "Under the Spell of John Philoponus: How Chalcedonian Theologians of the Late Patristic Period Attempted to Safeguard the Oneness of God," JTs, 68 (2017), pp. 625-649. 
Barmin's theological commentaries contain a very pertinent observation. In $\S 8$ of the First Antirrhetics, Eustratius continues his interpretation of the gospel saying Pater meus maior me est (John 14:28) (pp. 14/15-16/17 txt/Russ. tr.). Shortly before, he interpreted it traditionally - in the sense of $\mu$ ovapxi $\alpha$ of the Father (the Father is the unique "cause" of the three hypostases). Now, he refutes those who understand these words as said by Jesus according to the humanity in respect to the divinity. Barmin justly notes that here Eustratius goes against the future councils of 1166 and 1170, which proclaimed both interpretations orthodox (p. 15, fn. 4). Indeed, let us add to Barmin's commentary, Eustratius did so out of his "Nestorian" conviction that "...if the Saviour calls the Father his father as that of a human, he says that is what is not and pronounces

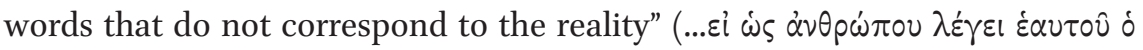

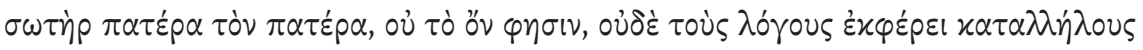

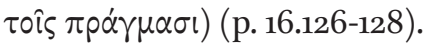

\section{Triadology and Logic}

The theological problems that such professional logicians as Eustratius and already John Philoponos were attempting to resolve did not allow logically consistent - that is, free of contradictions - decisions. Some Byzantine authors have spent buckets of ink to explain the need of logical inconsistencies for modifying the ancient Greek logic in conformity with Christian truths ${ }^{24}$ but some others, including Eustratius, were following Philoponos's program of contradiction-free Christian theology. The discussion about the Filioque, at least, since 1112 on, has been marked with this opposition of logical "programs" used in theology. As Barmin showed, Eustratius "program" has been accepted

24 Cf. S. Gerogiorgakis, "The Byzantine Liar," History and Philosophy of Logic, 30 (2009), pp. 313-330 (on inconsistent logics in the Triadology of Gregory of Nazianzus but without discussing the properly theological side of the problem); B. Lourié, "Nicephorus Blemmydes on the Holy Trinity and the Paraconsistent Notion of Numbers: A Logical Analysis of a Byzantine Approach to the Filioque," Studia Humana 5 (2016), pp. 40-54; idem, "A Logical Scheme and Paraconsistent Topological Separation in Byzantium: InterTrinitarian Relations according to Hieromonk Hierotheos and Joseph Bryennios," in: Relations: Ontology and Philosophy of Religion, ed. D. Bertini and D. Migliorini. (Mimesis International. Philosophy, 24), [Sesto San Giovanni (Milano)], 2018, pp. 283-299; idem, "What Means 'Tri-' in 'Trinity'? An Eastern Patristic Approach to the "Quasi-Ordinals," Journal of Applied Logic, 6 (2019), pp. 1093-1107. 
and developed by latinophrones theologians starting from the very first among them, Niketas "of Maroneia."

The logical nature of Eustratius's triadological argumentation is the most explicit in the "mathematical" part of the Sermon on the Holy Spirit (still understudied, having been first published by Barmin in 2006). Here, Eustratius opposed to the Latin teaching schematised by him as linear (Father - Son

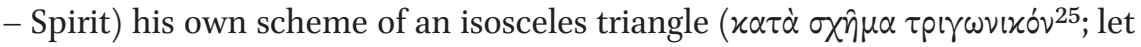
us translate "according to the triangle scheme"; see below on the meaning of the word "scheme" in my translation) with the Father at the top vertex and the Son and the Spirit at the two bottom vertices. The Trinity is, according to Eustratius, consisting of the Monad (Father) - that has the priority of being the cause of the Dyad (Son and Spirit) - and of the Dyad itself. He elaborated on the Neoplatonic, especially Pseudo-Iamblichus's teaching on the numbers, where both Monad and Dyad were considered as exempted from the further numeral row. ${ }^{26}$ Eustratius's own teacher John Italos left a short triadological treatise in the same vein (although not polemical). ${ }^{27}$ The basic numerological statement of Eustratius is the following:

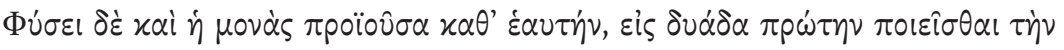

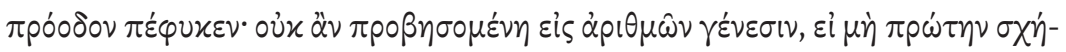

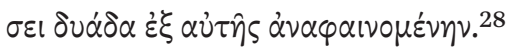

According to the nature, when the Monad is going forth by itself, it normally makes its proceeding to the first Dyad, because it would not step forward into generation of the numbers without previously having the Dyad appeared from it.

Бармин, Полемика и схизма, р. 556, line 559 .

26 Cf. especially the commented translation: The Theology of Arithmetic. On the Mystical, Mathematical and Cosmological Symbolism of the First Ten Numbers Attributed to Iamblichus. Translated from the Greek by R. Waterfield. (A Kairos Book), Grand Rapids, MI, 1988 (see here also on the Pythagorean background of this doctrine); A. Woszczyk, "Własności monady i diady w "Theologumena arithmeticae" przypisywanej Jamblichowi $\mathrm{z}$ Chalkis [Characteristics of the Monad and the Dyad in Theologumena arithmeticae Attributed to Iamblichus Chalcidensis (in Polish)]," Folia Filosophica 30 (2012), pp. 37-47; for a more remote Neoplatonic background of the numerological doctrine used by Eustratius, see S. Slaveva-Griffin, Plotinus on Number, Oxford, 2009.

27 Ioannes Italos, Quaestiones quodlibetales ('A tristica et byzantina, 4), Ettal, 1956, pp. 114-117 (Nr 69).

28 Бармин, Полемика и схизма, p. 546.15-18. 
Thus, in the Eustratius's scheme, any breaking of symmetry between the Son and the Spirit (such as the Filioque) would destroy the whole Trinity, because the Son and the Spirit would cease to form a dyad not overlapping with Father's monad. This scheme is clearly anti-Latin and consistent in the sense of containing no contradiction.

Let us make a remark on the importance of this place for the history of logic. Eustratius insists that the Monad and the Dyad, which together generate the numbers, form an adequate model of the Christian Tirinity - in such an extent that this model has been used by him for argumentation: some triadological ideas are, according to Eustratius, to be rejected simply because they are not fitting into his model. Eustratius's triangle ${ }^{29}$ is a graphical representation of propositions (not only of terms, as it was usual since antiquity in graphical charts illustrating logical and philosophical treatises) and is therefore appropriate for logical "calculations." Such schemes are now called "logical schemes" and are considered by the modern historians of logics as having first been proposed by Leonard Euler in 1763 (who, in turn, was elaborating on Leibniz's ideas); however, they became widespread in Byzantine theology in the twelfth century. ${ }^{30}$ Now we have to add that this was the case not without an important contribution of Eustratius.

Eustratius's scheme, of course, did not convince everybody. The Latins would have objected - and already Niketas "of Maroneia" implicitly objected that insisting on the perfect symmetry between the Son and the Spirit is somewhat inconsistent with the obvious asymmetry between the Father and the two other hypostases: if an asymmetry is allowed in this case, why it cannot be allowed in another case? Eustratius's answer was clear but hardly convincing for either Latins or Greeks: this would contradict the (Pseudo-Iamblichian) teaching on generation of the numbers, where the Monad must state that which is first and alone and the Dyad must follow it as the next unity.

For Greeks, Eustratius's Triadology was not appealing not only because of its implied crypto-Nestorianism. His idea to preserve "natural" ( $\varphi v$ $\sigma \varepsilon l$, see the quote above) order of one, two, and three in the Holy Trinity was unacceptable either. In Byzantine patristics, starting from the Cappadocian Fathers in the fourth century, the number three applied to the three hypostases of God was never considered as identical to the number three known from arithmetic. In

29 Probably Eustratius never added a graphical scheme of this triangle to his manuscripts, but rather described in words both this scheme and the linear scheme that he ascribes to the Latins.

$30 \quad$ As a test case in this unexplored field, see Lourié, "A Logical Scheme." Further studies are needed, especially in theological works of Niketas "of Maroneia" and logical works of Nicephorus Blemmydes and his disciple Theodore Doukas Laskaris. 
particular, in the "three" applied to the Holy Trinity there was never an implication of "two": no pair is allowed in the Trinity. Gregory of Nazianzus commented on this "skipping," or "overstepping" of "two" between "one" and "three" with the reference to the material world where "two" is inevitable due to the dualism between the form and the matter (Oratio XXIII, 8). His direct disciple Evagrius Ponticus wrote (Capita gnostica VI, 10-13) that the Holy Trinity is different from the numerical triad in the fact that, in God, "three" is not preceded by "two" and not followed by "four." ${ }^{31}$ In the late Byzantine anti-Filioque polemics, the defenders of Byzantine Orthodoxy were also insisting on the need to exclude any kind of pairing within the Trinity. ${ }^{32}$ Indeed, these patristic triadological concepts were blatantly inconsistent, but they were inconsistent in their own logical way that is now called paraconsistent logic (the logic allowing subcontrary contradictions).

The problem of pairing within the Trinity has been discussed from a traditional Byzantine viewpoint in one of the Byzantine treatises on the Holy Spirit presented to Emperor Alexios Komnenos in 1112/1113, together with Eustratius's Sermon on the Holy Spirit. This is the On the Proceeding of the Holy Spirit (ch. 47) by Nicholas Mouzalon, ${ }^{33}$ then the recently ( $c a$ 1110) abdicated archbishop of Cyprus and, in a remote future (1147), patriarch of Constantinople. Nicholas explicitly rejected any idea of pairing within the Trinity and was not afraid to declare such an order of things "supernatural" - i $\pi \varepsilon \varphi \varphi v \varepsilon s$ in contrast to Eustratius's $\varphi \dot{\sigma} \sigma \varepsilon:$

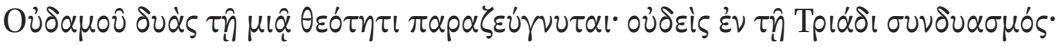

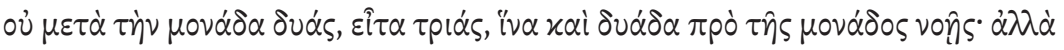

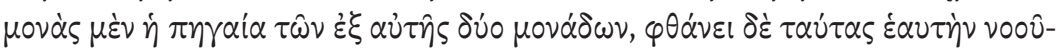

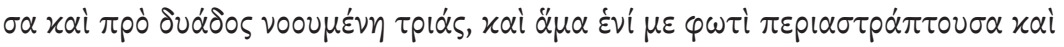

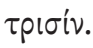

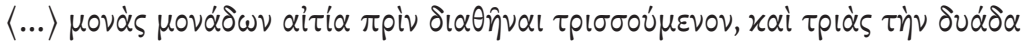

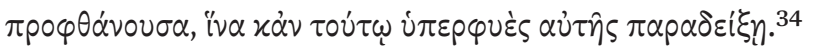

Nowhere is a dyad applicable to the unique divinity. There is no pairing in the Trinity. The monad is not followed by a dyad and then by a triad,

$31 \quad$ Lourié, "What Means 'Tri-' in 'Trinity'?"

32 Lourié, "Nicephorus Blemmydes on the Holy Trinity."

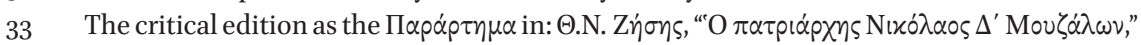

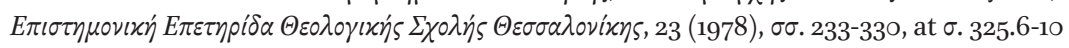
and 22-24.

34 The second passage is taken from the list of true statements that would become false if the Filioque is true. 
so that you would think a dyad before the monad, ${ }^{35}$ but the monad is the fountain [the term of the Areopagite, De div. nom. II, 7; PG 3, $645 \mathrm{~B}=$ ed. Heil, Ritter, p. 132.1] of the two monads which are from it, but it is preceding them thinking itself and being thought as the triad that is before the dyad and flashing around simultaneously as single and triple.

$\langle\ldots\rangle$ the monad is the cause of the monads, which is becoming triple before being disposed (in order), and the triad is preceding the dyad, so that, in this way, it will show forth its supernaturality.

Nicholas Mouzalon's future defender (at his trial in 1151) and the leading theologian of the twelfth century, Nicholas of Methone ( $c a$ 110os-1160/1166) in his refutation of Proclus (115os) made explicit that, in this "arithmetic," "one" is equal to "three," even though "one" and "three" remain clearly distinct ${ }^{36}$ :

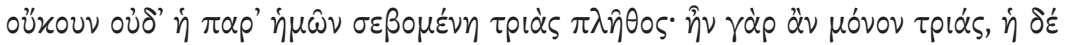

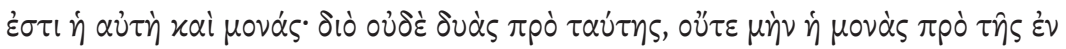

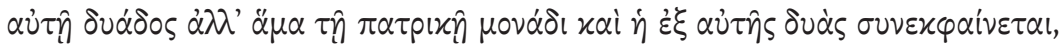

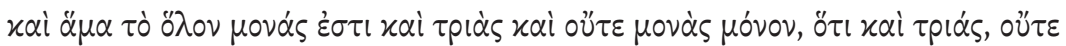

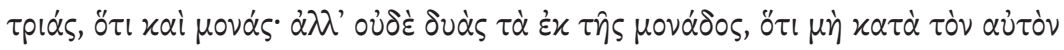

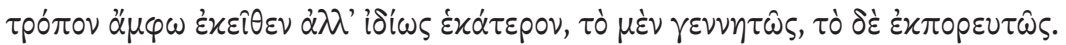

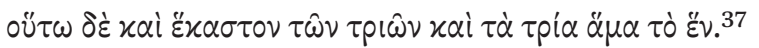

... Therefore, the Trinity/triad we are worshipping is not a multiplicity either, as it would be in the case if it were only a triad, but this triad is both triad and monad. Thus, neither the dyad is before it, nor the monad is before the dyad that is within it, but the paternal monad and the dyad that is from it are showing themselves simultaneously, and the whole is simultaneously monad and triad and not only monad but also triad, and not (only) triad but also monad. However, what is from the monad is not

35 In this chapter, Nicholas argued that, in the case of the Filioque, the Trinity would be decomposed into a monad causing a dyad, which, in turn, causes another monad; such a sequence where the monad is the cause of the dyad, and the dyad is the cause of the monad, would, in turn, generate other numbers beyond three, thus leading to a bad infinity.

36 For other instances of this equating " $1=3$," see Lourié, "What Means 'Tri-' in 'Trinity'?" and $i d e m=$ В. Лурье, "Понятие числа в триадологии восточной патристики [The Notion of Number in the Triadology of Eastern Patristics]," Esse, 1.1 (2016) <http://esse-journal. $\mathrm{ru} / \mathrm{p}=1713>$.

37 Nicholas of Methone, Refutation of Proclus's Elements of Theology. A critical edition with an introduction on Nicholas' Life and Works by A.D. Angelou. (Corpus philosophorum Medii Aevi. Philosophi byzantini, 1), Athens - Leiden, 1984, p. 135.24-31. 
a dyad, because the two are from it not in the same way, but each of the two in a specific way - one being born and another one proceeded. Thus, also each of the three is simultaneously three and one.

These quotations are sufficient to demonstrate that Eustratius's numerical rationalism was going against the mainstream Byzantine theological teaching of his epoch. No wonder that his Triadology was later called for by the latinophrones such as Niketas "of Maroneia." No wonder either that Eustratius's Triadology was rooted in Neoplatonic theological numerologies known to him both directly and via his teacher John Italos.

\section{$8 \quad$ Conclusion}

The above observations on Eustratius's texts first published by Barmin could serve to give, at least, a general idea of what mine of theological, philosophical, and logical thought Barmin opened to the scholarly community. We need to reward him, above all, with deeper studies of Eustratius and other understudied Byzantine authors of the twelfth and thirteenth centuries. ${ }^{38}$

38 The importance of the then unpublished works of Eustratius as sources of Niketas "of Maroneia" was noticed, with a reference to Barmin's 2000 paper, by Alessandra Bucossi, "Seeking a way out of the impasse: the Filioque controversy during John's reign," in: John II Komnenos, emperor of Byzantium: in the shadow of father and son, ed. A. Bucossi and A.R. Suarez. (Publications of the Centre for Hellenic Studies, King's College London), Farnham, 2016, pp. 121-134, at p. 129. 